\title{
RONDA MARIA DA PENHA: O ASSISTENCIALISMO PRESTADO PELOS POLICIAIS PARA COM AS VÍTIMAS DE VIOLÊNCIA DOMÉSTICA
}

\author{
SOUZA, THIAGO IZAC
}

Graduando em Direito, modalidade Integral - Escola Superior Dom Helder Câmara. Belo Horizonte- MG. E-mail: izac763@gmail.com.

CAIO AUGUSTO SOUZA LARA Mestre e Doutor em Direito pela Faculdade de Direito da Universidade Federal de Minas Gerais - UFMG. Professor da Escola Superior Dom Helder Câmara. Pesquisador Associado ao Programa RECAJ-UFMG - Acesso à Justiça e Solução de Conflitos. Secretário de Comunicação do Conselho Nacional de Pesquisa e Pósgraduação em Direito - CONPEDI. Belo Horizonte-MG. E-mail: caiolarabh@yahoo.com.br.

\section{RESUMO}

O tema-problema da pesquisa que se pretende desenvolver é o assistencialismo prestado por policiais militares às mulheres vítimas de violência doméstica no Estado da Bahia, que conta com apoio da Secretaria Baiana de Política para as Mulheres e de Segurança Pública, da Defensoria Pública, do Ministério Público e do Tribunal de Justiça do mesmo Estado. De acordo com os dados de um levantamento feito pelo BBC News (2019), encomendado pela ONG Fórum Brasileiro de Segurança Pública (FBSP) para avaliar o impacto da violência contra as mulheres no Brasil, foi constatado que, em um curto período de 12 meses, 1,6 milhão de mulheres foram espancadas, enquanto 22 milhões de brasileiras passaram por algum tipo de assédio. Ademais, entre os casos de violência, $42 \%$ ocorreram em ambiente 
Personalidade Acadêmica Homenageada:

Raymundo Juliano Feitosa (Universidade Federal do Rio Grande do Norte - UFRN)

doméstico e, o mais preocupante, mais da metade das mulheres (52\%) não denunciaram o agressor ou sequer pediram ajuda para alguma autoridade (FRANCO, 2018). Desse modo, é perceptível constatar como as medidas públicas adotadas pelo Governo Federal baseadas apenas em legislações são insuficientes para garantir o completo bem-estar e garantia dos direitos fundamentais das mulheres. Por conseguinte, é importante ressaltar o trabalho da Ronda Maria da Penha e as medidas protetivas de urgência os quais contam com o apoio do Ministério Público, ambos imprescindíveis para que seja feito o combate efetivo à violência doméstica, haja vista que acolhem o agressor e a mulher vítima de violência doméstica, salienta-se, assim, o caráter cautelar, didático e socializador da norma. O problema objeto da investigação científica proposta é: como o Estado da Bahia se posiciona diante de ocorrências envolvendo mulheres vítimas de violência doméstica? Quais medidas são adotadas para a prevenção e repressão de atos de violações de dignidade do gênero feminino no enfrentamento à violência doméstica e familiar? A partir das reflexões preliminares sobre o tema, é possível afirmar inicialmente que o Estado da Bahia conta com um trabalho especializado para mulheres vítimas da violência doméstica, contando com o suporte das esferas civis, militares e jurisdicionais, o que permite a maior proteção da vítima, colaborando para a prevenção de demais tentativas de agressão e punição do agressor. Entende-se que esse serviço corrobora a eficácia das medidas protetivas, o que consolida a reintegração e empoderamento da mulher na vida em sociedade. $O$ objetivo geral do trabalho é analisar a eficácia das medidas adotadas pelo Estado da Bahia contra a violência doméstica. A pesquisa que se propõe pertence à vertente metodológica jurídico-sociológica. No tocante ao tipo de investigação, foi escolhido, na classificação de Witker (1985) e Gustin (2010), o tipo jurídico-projetivo. O raciocínio desenvolvido na pesquisa será predominantemente dialético. De acordo com a técnica de análise de conteúdo, afirma-se que se trata de uma pesquisa teórica, o que será possível a partir da análise de conteúdo dos textos, doutrinas, normas e demais dados colhidos na pesquisa. A partir do exposto, concluise preliminarmente que o projeto Ronda Maria da Penha tem como fundamentação a busca pela garantia dos direitos das mulheres e, portanto, faz-se necessário 
Personalidade Acadêmica Homenageada:

Raymundo Juliano Feitosa (Universidade Federal do Rio Grande do Norte - UFRN)

disponibilizar um atendimento especializado, fornecendo agentes preparados que saibam acolher a vítima, com o fito de garantir segurança, bem como, motivá-las a prestarem queixa contra os agressores, tornando evidente que o vínculo emocional não pode retardar ou impedir que as vítimas de violência doméstica denunciem seus agressores. Outrossim, é notável que o projeto Ronda Maria da Penha visa a educação, porque desconstrói argumentos machistas e patriarcais em toda a sociedade, e consequentemente, reeduca ativamente os agressores, os quais participam de rodas de discussão com policiais militares que trabalham na operação.

PALAVRAS-CHAVE: Violência Doméstica; Ronda Maria da Penha; Assistencialismo Policial; Combate à Violência Doméstica.

\section{REFERÊNCIAS}

ABETTE, Eduardo Luiz Santos. Anotações críticas sobre a lei de violência doméstica e familiar contra a mulher. Disponível em: www.jusnavigandi.com.br. Acesso em 03 de abr. de 2019.

AS GRANDES navegações. SÓ HISTÓRIA. Disponível em: www.sohistoria.com.br/ef2/navegacoes/. Acesso em 08 de maio de 2019.

DEL PRIORE, Mary (Org.). História das mulheres no Brasil. São Paulo: Contexto, 2006.

EXPLICANDO o modelo de família patriarcal. Recanto das letras. Disponível em: https://www.recantodasletras.com.br/artigos/1160338. Acesso em 15 de abr. de 2019.

GUSTIN, Miracy Barbosa de Sousa; DIAS, Maria Tereza Fonseca. (Re)pensando a pesquisa jurídica: teoria e prática. 3ª . ed. Belo Horizonte: Del Rey, 2010.

PEREIRA, Ana Paula Camargo. Políticas públicas: um caminho para a promoção dos direitos humanos das mulheres em situação de violência doméstica e familiar. Revista Jurídica - UNICURITIBA, Curitiba, v. 22, n. 6, p. 167-188, 2009. Disponível em http://revista.unicuritiba.edu.br/index.php/RevJur/article/view/112/87. Acesso em: 21 mai. 2019. 
Personalidade Acadêmica Homenageada:

Raymundo Juliano Feitosa (Universidade Federal do Rio Grande do Norte - UFRN)

RONDA MARIA DA PENHA no combate à violência contra a mulher. Sou mais a Bahia. Disponível em: www./soumaisabahia.com.br/noticias/ronda-maria-da-penha/. Acesso em 1 de maio de 2019.

WITKER, Jorge. Como elaborar uma tesis en derecho: pautas metodológicas y técnicas para el estudiante o investigador del derecho. Madrid: Civitas, 1985. 